\title{
RESEARCH PAPER \\ SOLAR DRYER WITH BIOMASS BACKUP HEATER FOR DRYING FRUITS: DEVELOPMENT AND PERFORMANCE ANALYSIS
}

\author{
T. B.Tibebu ${ }^{1}$, G. Y. Obeng ${ }^{2}$, E. Mensah ${ }^{3}$ and A. Smith ${ }^{4}$ \\ ${ }^{1,3}$ Department of Agricultural Engineering, College of Engineering, KNUST, Kumasi \\ Email: tiruworkberhanu@gmail.com \\ ${ }^{2}$ Technology Consultancy Centre, College of Engineering, KNUST, Kumasi \\ Email: geo_yaw@yahoo.com \\ ${ }^{4}$ D-Lab, Massachusetts Institute of Technology, 265 Massachusetts Avenue, Bldg. N51-309, \\ Cambridge, MA 02139, USA
}

\begin{abstract}
Most solar dryers rely on only solar energy as the heat source. This condition limits its use in off -sunny periods such as cloudy, rainy seasons and after sunset. The objectives of this study were to: develop a solar dryer with biomass backup heater for drying fruits; analyze its performance; and carry out comparative analysis of the dryer with and without biomass backup heater. An indirect solar dryer was designed, constructed and analysed using $4 \mathrm{~mm}$ slices of pineapples and mangoes. Temperature, humidity and ambient air temperature were measured using Tinytag data loggers, EasyLog - USB 2 and HI 91610C Thermo-hygrometer. A $300 \mathrm{~g}$ weight of charcoal, costing GHC 0.5 (US\$ 0.16)was fed into the backup heater every 1-2 hours with a running cost of US\$ 1-2.88/day. The results showed that the moisture content $(M C)$ of the pineapples reduced from $87 \%$ to $16 \%(w b)$ and that of mangoes reduced from $85 \%$ to $15.5 \%(w b)$. On average, solar drying with backup took 14-18 sunshine hours to attain the desired MC, while that without backup took 20-27 sunshine hours. With biomass backup heater the drying rates were: pineapples $(32.5 \mathrm{~g} / \mathrm{h})$ and mangoes $(19.3 \mathrm{~g} / \mathrm{h})$, while without backup the drying rates were: pineapples $(23.7 \mathrm{~g} / \mathrm{h})$ and mangoes $(15.5 \mathrm{~g} / \mathrm{h})$. Better performance was obtained when the dryer was with a biomass backup heater.
\end{abstract}

Keywords: Moisture, dryer, temperature, solar, biomass

\section{INTRODUCTION}

High moisture content of some harvested agricultural produce can facilitate the growth of microorganisms, which results in spoilage. Reducing the moisture content of most foods to 10 $-20 \%$ prevents bacteria, yeast, mold and enzymes from damaging them (Scanlin, 1997).
Hence, in order to reduce postharvest loses to enable farmers increase the quality of their produce, efficient and affordable drying methods are necessary.

Drying is a process of moisture removal due to simultaneous occurrence of heat and mass 
transfer (Ertekin and Yaldiz, 2004). Heat transfer occurs to change the temperature of the material to be dried and mass transfer occurs when moisture is removed from within the material to the surface accompanied by evaporation from the surface to the surrounding atmosphere (Hii et al, 2012). For successful drying, enough heat should be applied to draw out moisture without cooking the food and adequate dry air circulation should be allowed to carry off the released moisture. In addition, the moisture must be removed as quickly as possible at a temperature that does not seriously affect flavor, texture and colour of the food (Sanni et al, 2012).

Drying is an old technique used for food preservation. It can reduce wastage of surplus production and also make produce lighter, smaller and easier to handle (Green and Schwarz, 2001). It is a very suitable preservation technique for developing countries with poorly established low-temperature and thermal processing facility (Hii et al, 2012). Drying can ensure continuous food supply and production of high quality marketable produce (Weiss and Buchinger, 2002). Traditional open sun drying is a common and widely used method for drying of agricultural produce including fruits, vegetables and cash crops. It is the simplest way of drying foods by direct exposure of the product to the sun. Even though sun drying is the cheapest method, the quality of the dried product usually falls below standards due to contamination, damage by birds or insects and slow or intermittent drying (Brenndorfer et al, 1987). Dried product quality improvement and reduction of losses can be achieved by the introduction of suitable drying technologies such as solar drying.

Solar dryers constitute a specialized structure that controls the drying process and protect the produce from damage by dust, rain and insects. (Raju et al, 2013). Since the products are protected and the drying time is reduced significantly, the quality of dried product obtained by solar drying is better than that of sun drying. (Seveda, 2013).
However, most solar dryers use only solar energy as a heat source for drying. This makes such solar dryers dependent on climatic conditions limiting their use in off-sun periods. The consequence is that agricultural produce that are harvested during the rainy seasons are likely to decompose without proper handling. Therefore there is the need for continuous research and development of additional techniques for heat supply to enhance solar drying.

The objectives of this study were to develop a solar dryer with biomass (charcoal) backup heater for drying fruits; evaluate performance by analyzing temperature, moisture content and drying rate and carry out comparative analysis of the solar dryer with and without biomass backup heater for future adoption and scale-up.

\section{MATERIALS AND METHODS}

An indirect solar dryer was developed by design and construction. It comprises four major components - solar flat plate collector, drying chamber, chimney and biomass backup heater attached to the drying chamber. The dryer was designed using Siemens NXsoftware. It has the following dimensions: length $1963 \mathrm{~mm} \mathrm{x}$ breadth $630 \mathrm{~mm}$ x height $2160 \mathrm{~mm}$. Fig. 1 shows the isometric drawing of the dryer. Its pictorial view is shown in Fig. 2.

Data collection and performance analysis of the dryer were carried out from January to February 2015 at the Kwame Nkrumah University of Science and Technology (KNUST) in Kumasi, Ghana - Latitude $6^{\circ} 42^{\prime} \mathrm{N}$ and longitude $1^{\circ} 57^{\prime} \mathrm{W}$ (Moujaled, 2014). According to measurements done by the Meteorological Services Department of Ghana and the KNUST, average solar irradiation for Kumasi was $340.8 \mathrm{~W} / \mathrm{m}^{2}$. The ambient temperature, $\mathrm{T}_{\mathrm{a}}$, of the test location was $27-32^{\circ} \mathrm{C}$ with relative humidity of $70-84 \%$ (Forson et al, 2007 and Antwi, 2007).

\section{Construction of the solar dryer}

As already mentioned the dryer comprised four major components. The following subsection provides a description of the components. 


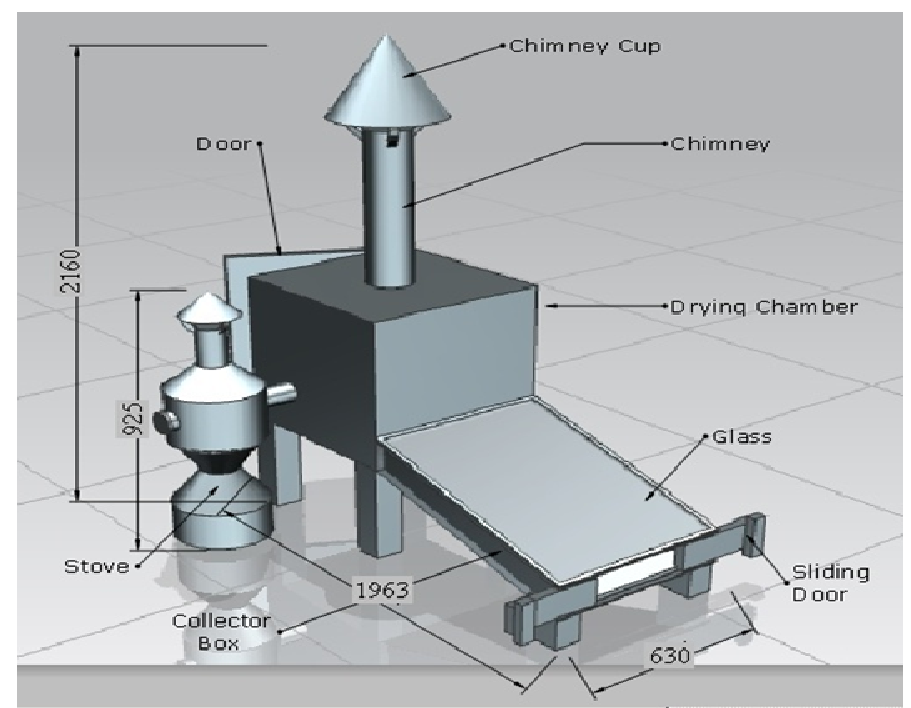

Fig. 1: Isometric view of the designed solar dryer with backup heater

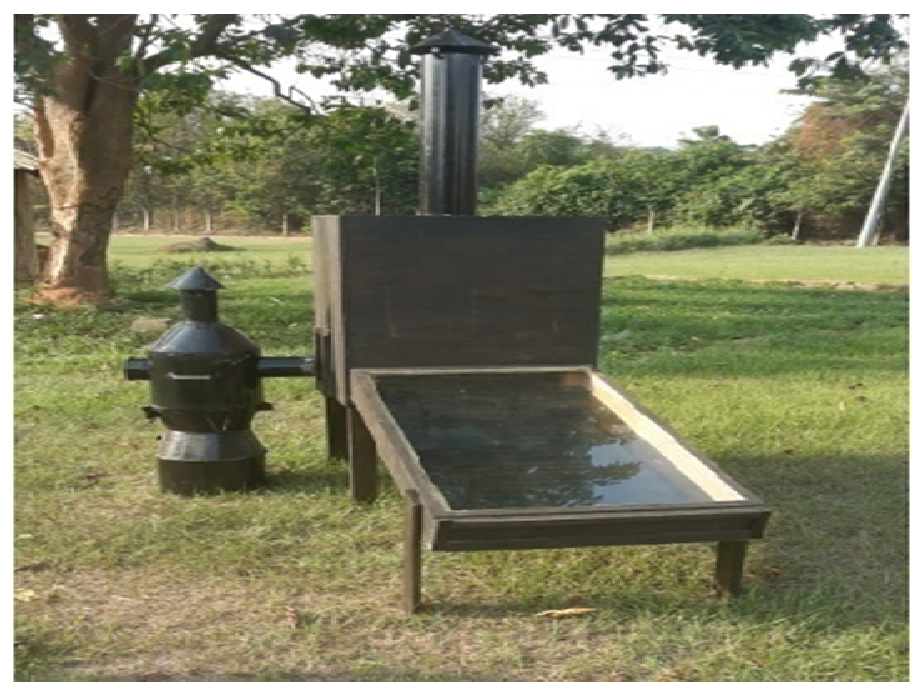

Fig. 2: Experimental set up of the constructed solar dryer with backup heater

The collector, drying chamber, chimney and backup heater

The collector

The collector's length and breadth are $1115 \mathrm{~mm}$ $\mathrm{x} 630 \mathrm{~mm}$ and it has a transparent cover, absorber plate and insulation. The transparent cover was made from a single layer glass of 5 $\mathrm{mm}$ thickness. Aluminum sheet of $2 \mathrm{~mm}$ thick- 
ness, painted black, was used as an absorber. To minimize heat loss from the absorber plate, $3 \mathrm{~mm}$ thick fiber glass insulation was used. The collector casing was made from wood and plywood. The air inlet opening was covered with mosquito net to prevent insect entry into the drying chamber where the fruits are dried. A sliding door was designed and constructed to control airflow into the drying chamber.

\section{The drying chamber}

The drying chamber was made from plywood and wood support. It has three trays- top tray (Tray 1), middle tray (Tray 2) and bottom tray (Tray 3), each of size $60 \mathrm{~mm}$ x $50 \mathrm{~mm}$. The trays were made from perforated stainless steel sheet. Stainless steel was chosen to avoid rusting and contamination of the fruits during drying. On one side of the chamber, a circular hole of $10 \mathrm{~mm}$ diameter was made to allow hot air from the burning of charcoal pass through a metal pipe into the chamber as backup during drying. A sliding door was designed to cover the hole when the stove was not connected. At the back of the drying chamber, a door was provided for loading and removal of drying materials.

\section{The chimney}

The chimney was constructed from $1 \mathrm{~mm}$ galvanized sheet that was rolled and welded to a 15 $\mathrm{mm}$ diameter cylinder. A cup was placed at the top of the chimney to prevent rain from entering the dryer. The chimney was painted black to facilitate the flow of hot air through the drying chamber.

\section{The biomass backup heater}

The biomass backup heater uses charcoal as fuel. A Jico-type improved cook stove with ceramic lining known as "Gyapa" was used. To avoid smoke and flue contamination of the fruits the heat supplied from the cook stove to the drying chamber was collected through a cylindrical metal duct, which connects the backup heater to the drying chamber. The metal duct was welded at the center of a cylindrical cover, which was used to trap the heat.
This cover was well insulated using $2 \mathrm{~cm}$ thickfiber glass. Cold air, which passed through the hot metal duct picked up heat from the hot metal surface and transferred it to dry the fruits. The smoke from the heater escaped through a chimney, which was connected at the top of the cover. Once the smoke from the charcoal had flown out, the chimney is covered to prevent the escape of heat.

\section{Production and running costs}

The total cost of producing the solar dryer with backup heater was GH $\varnothing 1050$ (US\$ 330) in February 2015. Since the solar dryer depends primarily on energy from the sun which is free, the recurrent energy cost would be estimated as follows based on the use of biomass in the form of charcoal - If $300 \mathrm{~g}$ of charcoal costing GHC 0.5 (US\$ 0.16) is fed into the backup heater every two hours during day time (06:00 to 18:00 hours), then the estimated cost would be US\$ $0.16 \times 12$ hours $\times$ charcoal fed/2 hours = US\$ 0.96. Again, charcoal fed into the backup heater after sunset (18:00 to 06:00 hours) is estimated to cost US\$ $0.16 \times 12$ hours $\times$ charcoal fed $/ 1$ hour $=$ US\$ 1.92 . Hence, the total cost of charcoal/day is estimated at US\$ $0.96+$ US\$ $1.92=$ US\$ 2.88/day for an estimated quantity of charcoal of $5.4 \mathrm{~kg} /$ day. Since the price of charcoal varies from locality to locality and the price is cheaper in rural communities, the recurrent cost of the solar dryer with biomass backup when it is used in rural locations is estimated to be $40-50 \%$ of the price of charcoal sold in the city, implying a running cost of about US\$ 1 - 1.44/day. In summary, the running cost of the solar dryer with biomass backup would be US\$ $1-2.88$ / day.

\section{Material preparation for drying}

Fresh pineapples and mangoes were obtained from the local market in Kumasi. They were washed, peeled and sliced into pieces. According to Solar Flex (2013), slices for very wet fruits like pineapple should not be more than approximately $5 \mathrm{~mm}$ thick. On the other hand, FAO (1997) suggests the slice thickness for pineapple should be 2-3 mm. For the perform- 
ance tests, average slice thickness of $4 \mathrm{~mm}$ of pineapples and mangoes were used. The sliced pineapples and mangoes were placed separately on single layer trays - top tray (Tray 1), middle tray (Tray 2) and bottom tray (Tray 3) to avoid the trapping of moisture at the tray edges.

\section{Instruments used for data collection}

The parameters measured during the evaluation of the solar dryer included moisture content, temperature and drying rate. The temperature and humidity inside the dryer and collector as well as the ambient temperature were measured using Tinytag data loggers, EasyLog - USB 2 and HI 91610C Thermo-hygrometer. The thermometer and the hygrometer were set to record data every one hour. At the end of each test, the thermos-hygrometer was taken out and the data was transferred to a computer. Solar Power Meter TM-206, TENMARS was used for measuring the solar insulation and EA-3010U Anemometer was used for measuring wind speed. Additional data was also obtained from a Solar Laboratory of KNUST. The weighing scale used was SOEHNLE. The initial weight of the fruits to be dried was weighed before placing in the dryer. Once the drying started, the produce being dried was taken out from the dryer every three hours for the weight to be measured.

\section{Dryer performance evaluation tests}

The performance of the solar dryer with and without the backup heater was evaluated focusing on moisture content, temperature and drying rate. No-load and load test were performed separately. During the no load test the solar dryer was tested without any fruits. The load test of the solar dryer was carried out using 1 $\mathrm{kg}$ each of the fresh slices of pineapples and mangoes. The slices were put on three separate single-layer trays. This helped to avoid overlapping and ensured uniform drying.

From the different tests carried out it was found that $2-2.5 \mathrm{~kg}$ of pineapples of $5-8 \mathrm{~mm}$ diameter and $1.5-2.5 \mathrm{~kg}$ of mangoes could be dried in a batch. Ambient temperature and humidity, dryer temperature and collector output temperature were recorded every one hour interval, while the weight of the produce kept in the dryer was measured every three hours interval. The drying rate was also determined. In each test, drying continued until no further weight reduction was recorded. Table 1 shows the drying conditions.

Oven drying was used to determine the initial moisture content of the pineapples and mangoes. Moisture loss of the pineapples and mangoes were determined in the course of the drying by noting the initial moisture contents and measuring weights at regular intervals. Moisture content was determined on wet basis and dry basis. The moisture content on wet basis

Table 1: Drying conditions

\begin{tabular}{ll}
\hline Weight per batch of sliced fruits dried & $\mathbf{1 ~ k g / t r a y}$ \\
\hline & \\
Wind speed & $0.3-2.1 \mathrm{~m} / \mathrm{s}$ \\
Ambient temperature & $27-32^{\circ} \mathrm{C}$ \\
Relative humidity outside & $79.7 \%$ \\
Relative humidity inside drying chamber & $21.9 \%$ \\
Average daily solar insolation & $394.8 \mathrm{~W} / \mathrm{m}^{2}$ \\
Location of study & Kumasi, Ghana \\
Latitude & $6^{\circ} 42^{\prime} \mathrm{N}$ \\
longitude & $1^{\circ} 57^{\prime} \mathrm{W}$ \\
\hline
\end{tabular}


was calculated using equation (1) (Fudholi, 2011):

MC (w. b.),$\%=\frac{w-d}{w} ; 100$

Dry basis moisture content is given by equation (2) (Mercer, 2007):

MC (d.b.) g water / g dry solids $=\frac{w-d}{d}$

Where,

$$
\begin{aligned}
& w=\text { weight of wet material } \\
& d=\text { weight of dry material }
\end{aligned}
$$

Another significant test that was carried out was the evaluation of the performance of the solar dryer with the backup heater. The backup heater supplied heat from $300 \mathrm{~g}$ of burning charcoal to the drying chamber. All measurements taken in the test were repeated to ensure consistency.

\section{RESULTS AND DISCUSSION \\ No-load test}

During the no-load test the solar dryer was tested without any fruits. The ambient air temperature averaged $34.2^{\circ} \mathrm{C}$. The average air temperature measured at the inlet of the collector was $41.3^{\circ} \mathrm{C}$ and at the outlet of the collector or inlet to the drying chamber was $56.4^{\circ} \mathrm{C}$. This indicated the temperature of streaming hot air that was likely to flow to the drying fruits. During the no-load test the cabinet was empty therefore the air temperature in the drying chamber rose from $30.4^{\circ} \mathrm{C}$ at $08: 00$ hours to $51.1-53.7^{\circ} \mathrm{C}$ at mid-day as shown in Fig. 3(a). A similar value was reported by Svenneling (2012) for an indirect solar dryer where the temperature rise in the drying chamber reached $50^{\circ} \mathrm{C}$ by mid-day.

When the ambient air temperature was $36^{\circ} \mathrm{C}$ at mid-day, the average air temperature measured in the drying chamber was $51.1^{\circ} \mathrm{C}$ - a temperature elevation of about $15^{\circ} \mathrm{C}$ above ambient air temperature. This value was relatively high compared to an indirect solar dryer constructed by Antwi (2007) who reported a temperature rise of $6.9^{\circ} \mathrm{C}$ above ambient air temperature. A similar indirect solar dryer test performed by Alonge and Adeboye (2012) resulted in a drying chamber air temperature of $48{ }^{\circ} \mathrm{C}$ when the ambient air temperature was $39^{\circ} \mathrm{C}$. A relatively high drying chamber temperature of $57.0^{\circ} \mathrm{C}$ with ambient air temperature of $33.5{ }^{\circ} \mathrm{C}$ was reported by Bolaji (2012) who designed a box type indirect crop dryer.

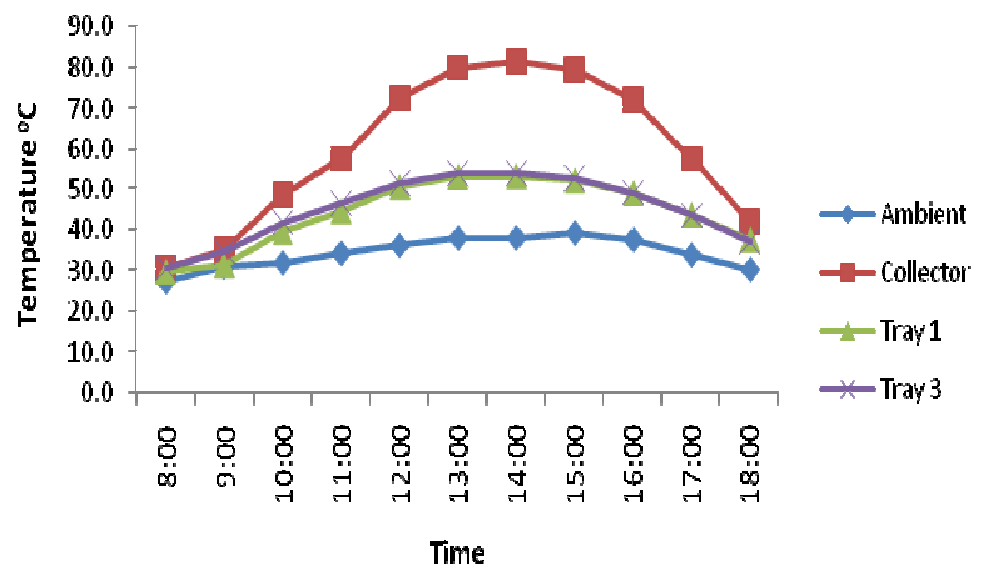

Fig. 3(a): No-load air temperature and time graph 
In the evening, the temperature in the drying chamber was kept higher than the collector or ambient air temperature by supplying heat from the backup heater. As a result, the temperature on the bottom tray (tray 3 ) could rise from 41.5 ${ }^{\circ} \mathrm{C}$ to $50.8^{\circ} \mathrm{C}$ in two hours $(19: 00$ to $21: 00$ hours) of backup heat supply. The average dryer temperature was found to be $47.8^{\circ} \mathrm{C}$ whereas the average ambient air temperature was about $24.2^{\circ} \mathrm{C}$. A higher temperature was recorded on the bottom tray (tray 3 ), which is near to the point where heat is supplied from the charcoal stove. To maintain this temperature, $300 \mathrm{~g}$ of charcoal, costing Ghф 0.5 (US\$ 0.16 ), was fed to the stove every one hour interval starting from 18:00 to 21:00hours. After sunset (19:00 to 02:00 hours), the collector temperature decreased from $30.5^{\circ} \mathrm{C}$ to $23^{\circ} \mathrm{C}$ and ambient air temperature also decreased from $26.9^{\circ} \mathrm{C}$ to $23^{\circ} \mathrm{C}$ as depicted in Fig. 3 (b).

Solar drying without biomass backup heater Moisture content of pineapple with time

Figs. 4 and 5 show the graphs of moisture content of pineapple with time on both wet basis and dry basis when solar energy was the only source of heat supply. The moisture content of the pineapples was reduced from $87 \%$ to $16 \%$ (w.b.) or $6.69 \mathrm{~g} \mathrm{H}_{2} \mathrm{O} / \mathrm{g}$ solids to $0.19 \mathrm{~g} \mathrm{H}_{2} \mathrm{O} / \mathrm{g}$ solids (d.b.) as in Fig. 5 within 23 sunshine hours ( 3 days) (see Figs 4 and 5). The value of the final moisture content falls within the standard range set by United Nations (2013a). According to this standard, untreated dried pineapple should have final moisture content not exceeding $18 \%$ (wet basis). As the inlet air passes through the collector and enters the drying chamber, it rises up in the drying chamber and picks up moisture from the fruits on the tray. This results in moisture loss of the pineapples. In order to reduce moisture re-absorption after sunset the drying chamber was kept closed using the sliding doors. Even though the dryer was closed during the night, it was observed that moisture re-absorption occurred at the end of the drying period. As a result, the moisture content of the pineapples being dried increased from $15.7 \%$ to $18.2 \%$ over the night of the third to fourth day as shown in Fig. 4.

\section{Drying of mangoes}

In solar drying of the mangoes, as shown in Figs. 6 and 7, the moisture content of the fruit was reduced from $85.0 \%$ (w.b.) to $13.3 \%$

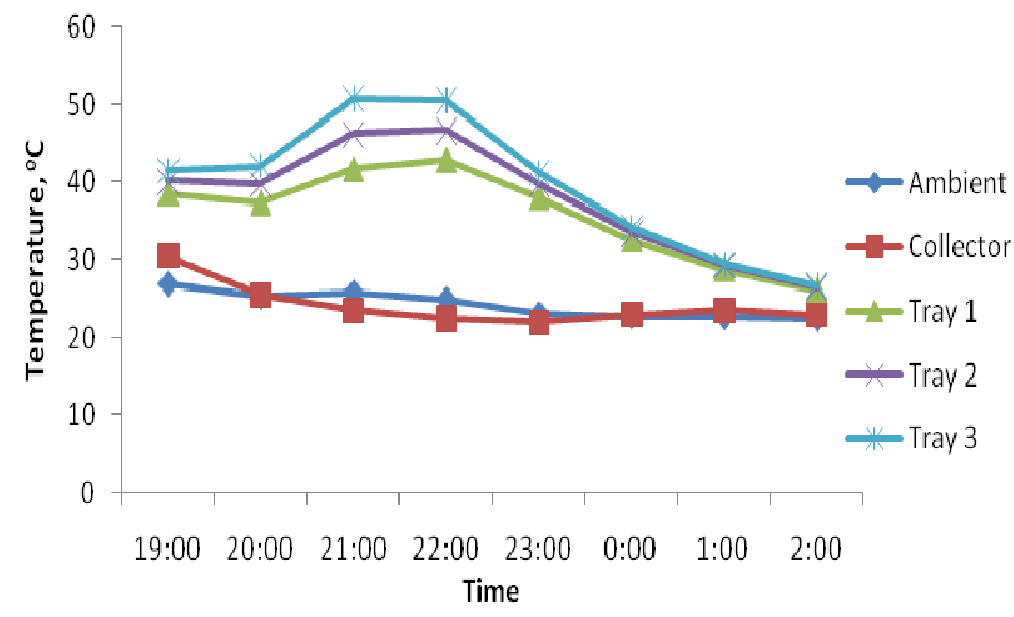

Fig. 3(b): No-load air temperature and time using backup heater 


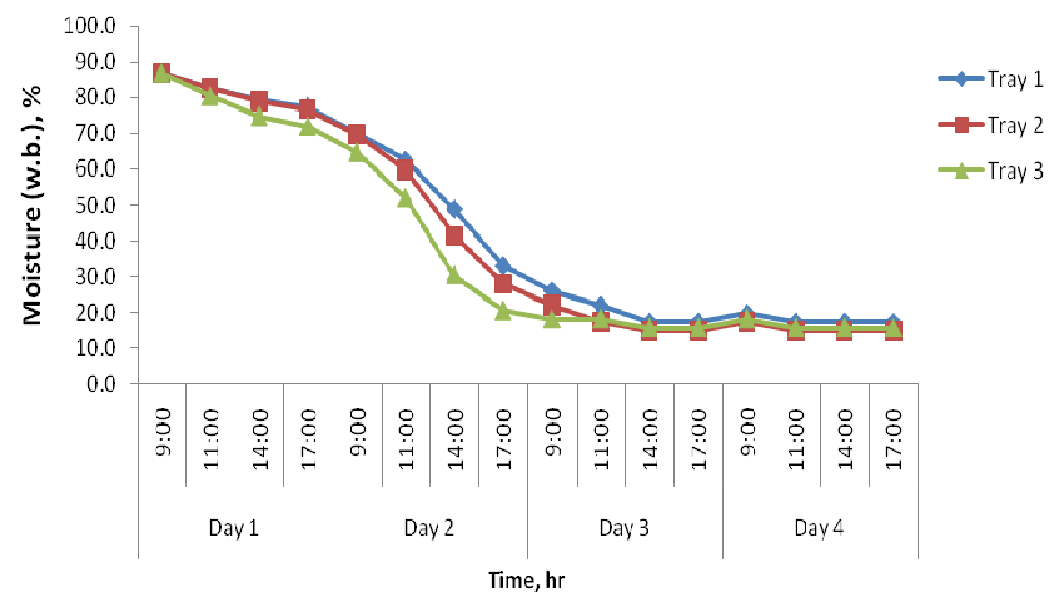

Fig. 4: Moisture content of the pineapples and time

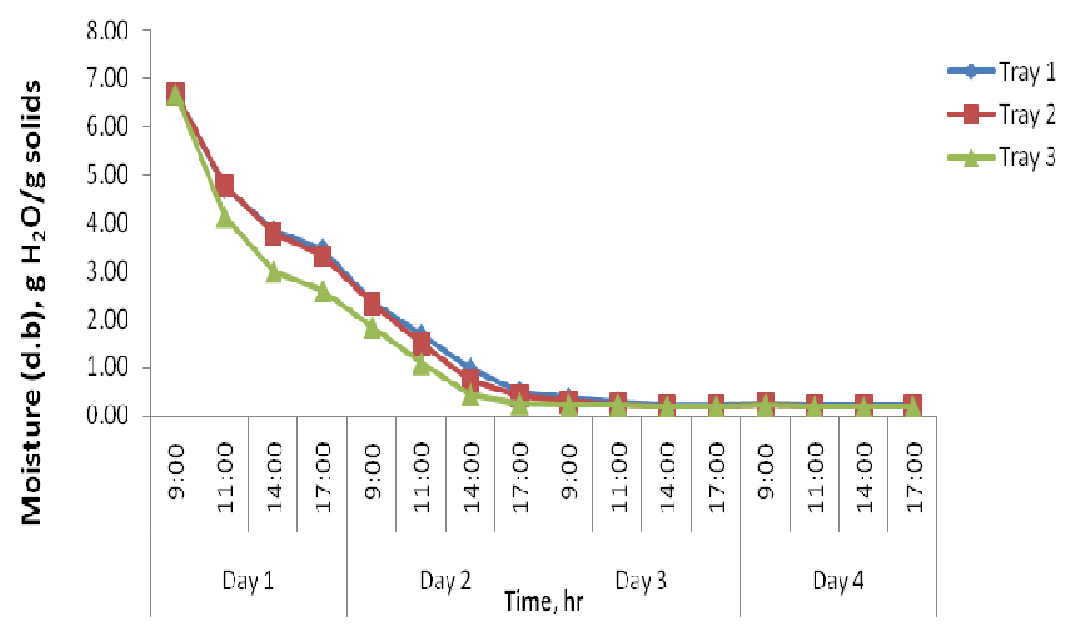

Fig. 5: Moisture content of the pineapples and time

(w.b.) or $5.67 \mathrm{~g} \mathrm{H}_{2} \mathrm{O} / \mathrm{g}$ solids (d.b.) to $0.15 \mathrm{~g}$ $\mathrm{H}_{2} \mathrm{O} / \mathrm{g}$ solids (d.b.) in two days. This value is consistent with United Nations (2013b) that set the final moisture content for a dried mango to be about $15 \%$ (wet basis). A natural convection direct type solar dryer constructed and tested by Akoy et al (2004) reported a moisture reduction from $81.4 \%$ to $10 \%$ w.b. in two days when drying mango. Lower moisture content of $10 \%$ was achieved within the same drying period as compared to the current dryer constructed. This can be attributed to the fact 


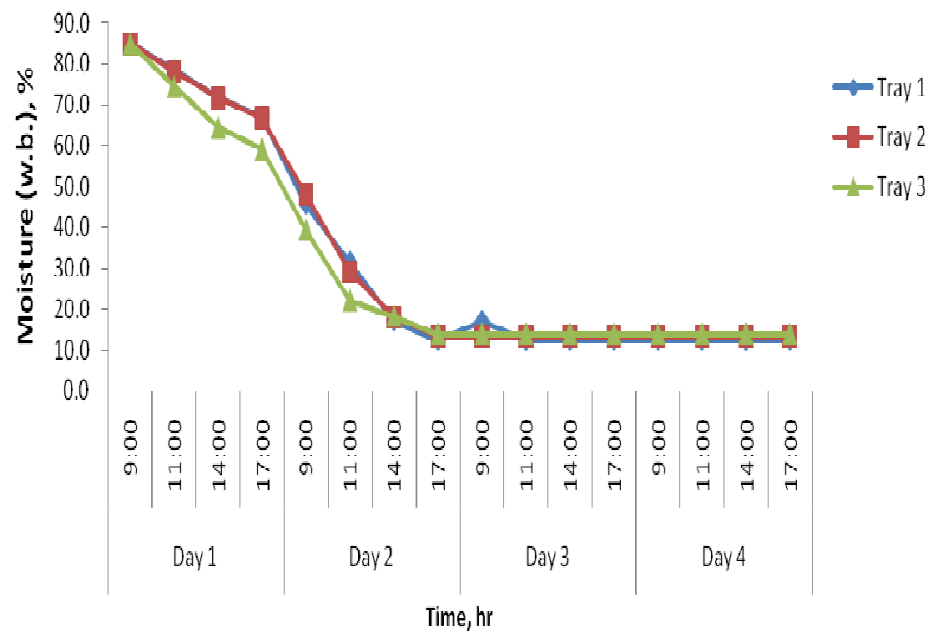

Fig. 6: Moisture content of mangoes and time

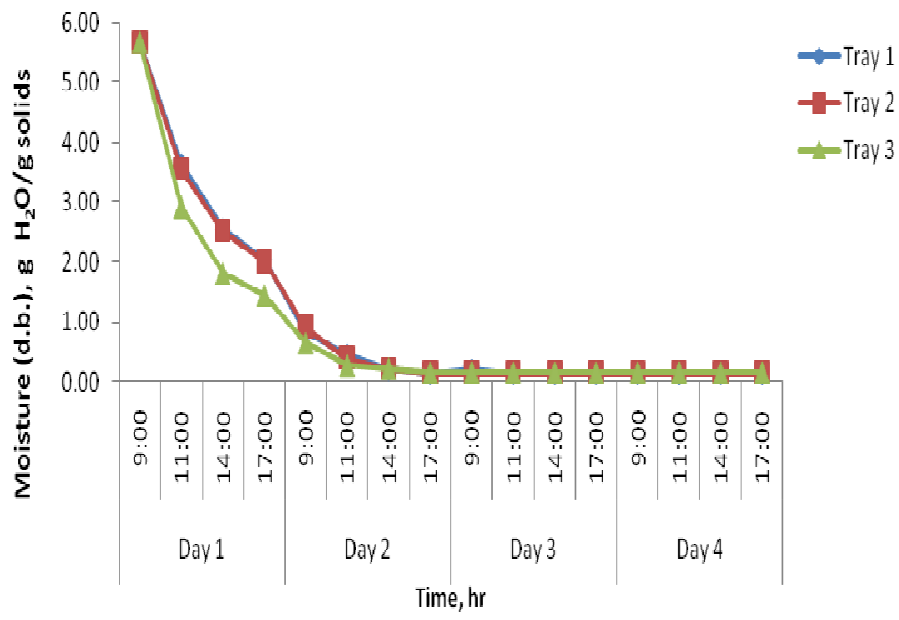

Fig. 7: Moisture content of the mangoes and time

that a higher drying temperature was recorded in the dryer as a result of direct exposure to the sunlight or direct type of solar dryer. Although the drying continued up to the fourth day, no moisture loss was observed after the second day. Re-wetting occurred during the night time of the third day of drying. This resulted in moisture re-absorption of about $1.5 \%$.

\section{Drying of pineapples and mangoes}

Fig. 8 shows the graphs of moisture content of mango and pineapple with time. From the 
graphs, the mangoes lost moisture faster than the pineapples. The results showed that it took about 18 sunshine hours ( 2 days) for the mangoes to reduce moisture content from $85 \%$ to $11.6 \%$, while in the case of the pineapples moisture reduction from $87 \%$ to $16 \%$ occurred in 27 sunshine hours ( 3 days). The implication is that less drying time is required to dry ma- ngoes than pineapples.

\section{Solar drying with backup heater}

Drying of pineapples

Solar drying with backup heater can provide a relatively fast drying as compared to solar drying without backup heater. The graph in Fig. 9 showed that it took about 20sunshine hours

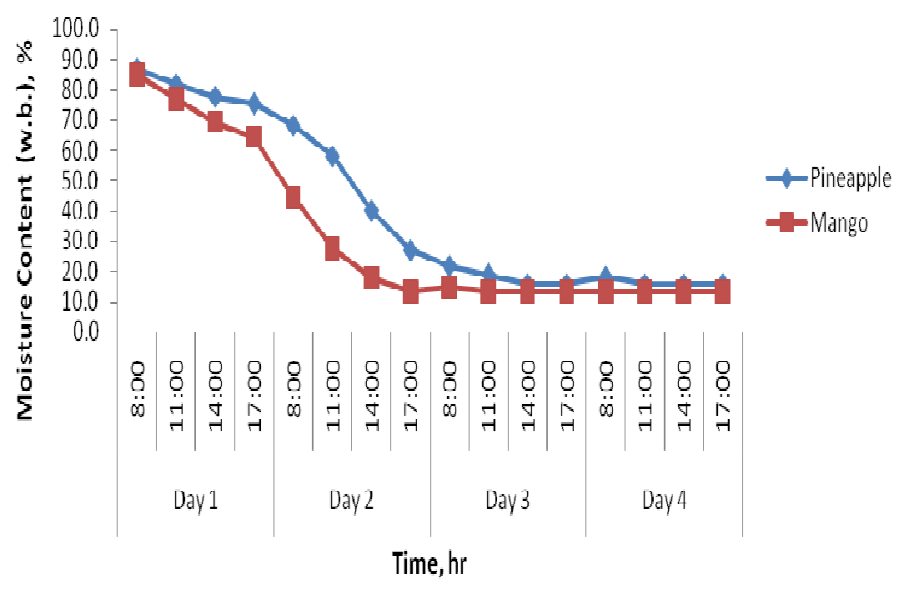

Fig. 8: Moisture content of the mangoes and pineapples with time

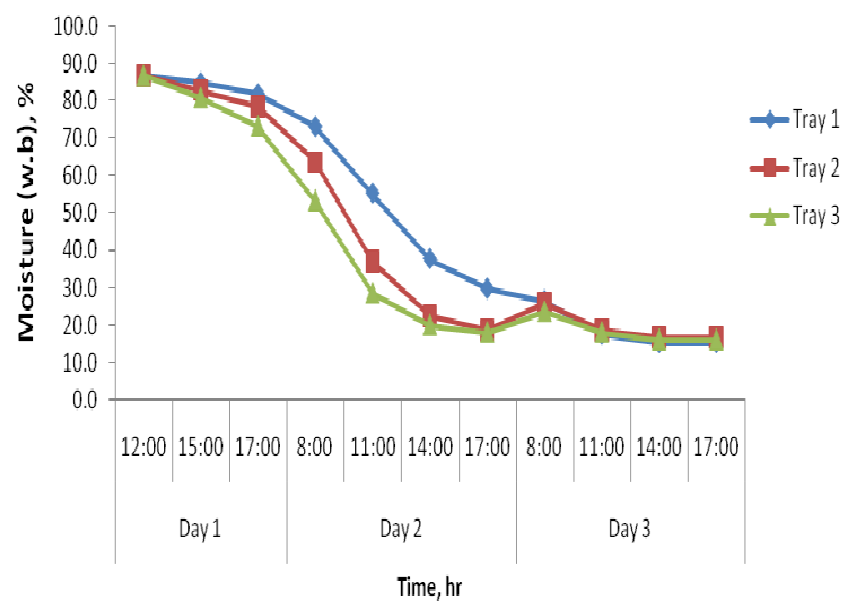

Fig. 9: Moisture content of the pineapple and time using solar dryer with backup heater 
(2.5 days) to reduce the moisture content of the pineapples from $87 \%$ to $16 \%$ (w.b.). About $300 \mathrm{~g}$ of charcoal costing GHC 0.5 (US\$ 0.16) was supplied every two hours interval during daytime and every one hour during evening. The result obtained in this test was comparable to the findings reported in Elepano and Satairapan (2001). In this paper, it took 18 hours for a solar dryer with biomass back up to dry pineapples from a moisture content of $85 \%$ to $20 \%$ (w.b.) at an average drying temperature of 60 ${ }^{\circ} \mathrm{C}$.

\section{Drying of mangoes}

Similarly, from the graph shown in Fig. 10, it took about 14 sunshine hours (2 days) to reduce the moisture content of the mangoes from $85 \%$ to $11.6 \%$ (w.b.). About $300 \mathrm{~g}$ of charcoal costing GHC 0.5 (US\$ 0.16) was supplied every two hours interval during day time and every one hour during evening.

\section{Solar drying with and without backup heater}

The moisture contents of the pineapples and mangoes with time using the solar dryer with and without the backup heater are indicated in Figs. 11 and 12. From the graphs, moisture loss occurred faster when the solar dryer was used with the backup heater. The results indicated gradual reduction in moisture content from 87 to $77 \%$ for the pineapples and from 85 to $70 \%$ for the mangoes within the first 5 hours of drying. From the graphs, it is seen that from midday to sundown the rate of moisture reduction increased for both fruits when the solar dryer was used with the backup heater. After continuous drying of the pineapples with backup heater, on the second day, the moisture content of the pineapples reduced from $26.8 \%$ to $22.3 \%$ around mid-day (Fig. 11), while using the solar dryer alone without the backup heater the moisture content of the pineapples reduced from $58.2 \%$ to $40.3 \%$ within the same time interval. Overall, moisture loss continued in both the solar dryer with backup and solar dryer without backup. However, it is likely that re-wetting and moisture absorption occurred overnight from 17:00 hours in Day 2 to 09:00 hours the next morning, hence the sudden rise in the dryer with backup graph.

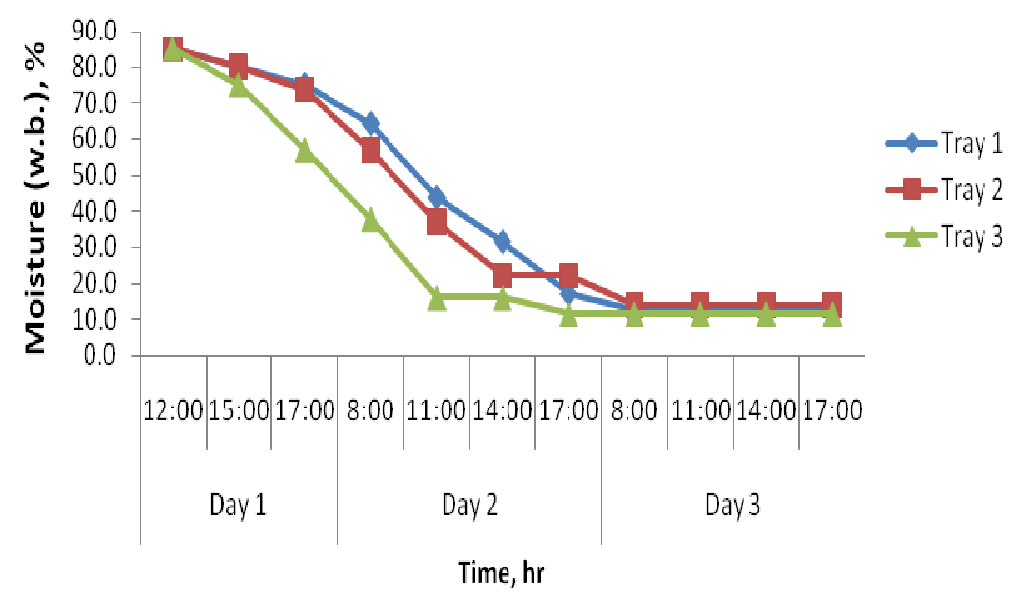

Fig. 10: Moisture content of the mangoes and time using solar dryer with backup heater 


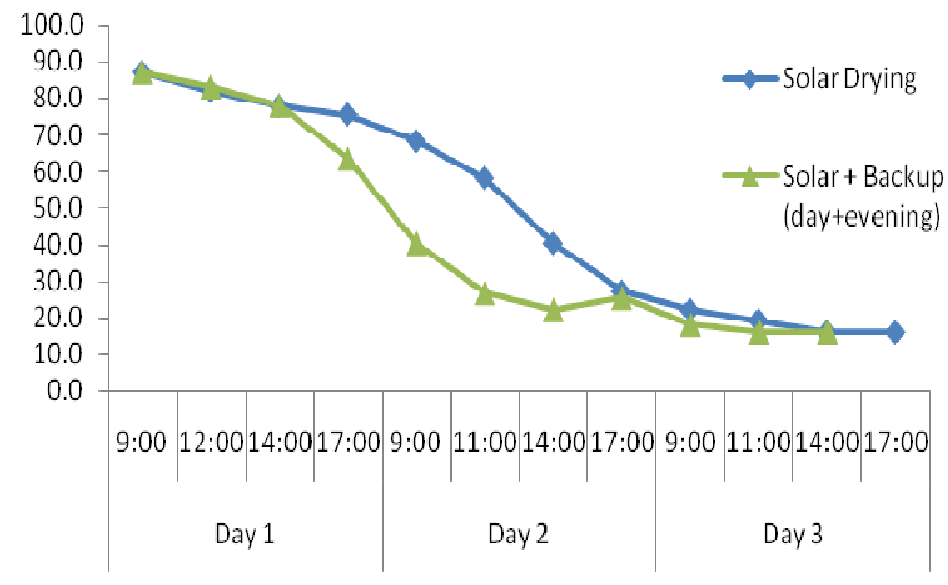

Fig. 11: Moisture content of the pineapples and time using solar dryer with and without backup heater

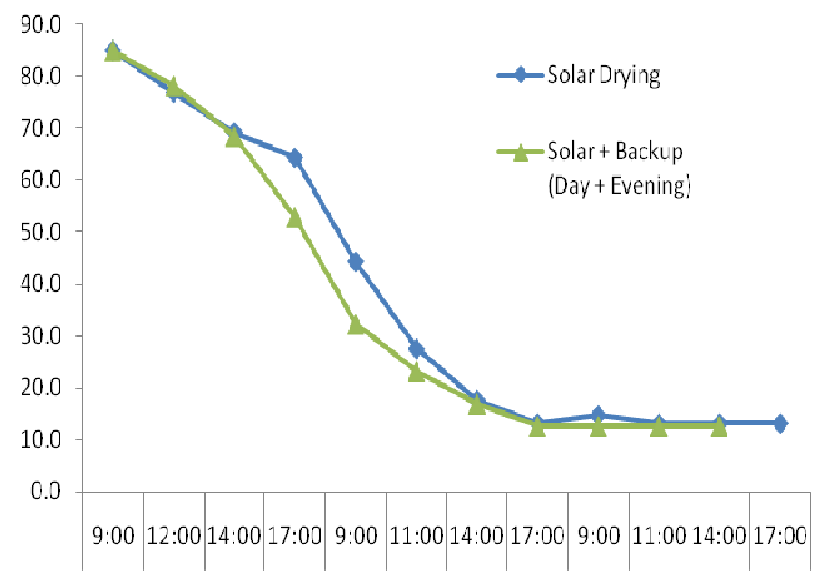

Fig. 12: Moisture content of the mangoes and time using solar drying with and without backup heater

In the case of the drying of mangoes, the moisture content measured around mid-day indicated $23.2 \%$ for solar drying with backup, while solar drying without back was $27.6 \%$ (Fig. 12). The graphs have indicated that mois- ture reduction is likely to be enhanced in a solar dryer with a backup heater.

\section{Drying rate}

The drying rates of the pineapples and mangoes 
using the solar dryer with and without backup heater are presented in Table 2 below. Using the solar dryer without backup heater, the drying rate of the pineapples was measured to be $23.7 \mathrm{~g} / \mathrm{h}$ whereas for mango it was $15.5 \mathrm{~g} / \mathrm{h}$. However, a higher drying rate was obtained when the solar dryer was used with backup heater. The study results showed that with backup heater, the drying rate of pineapples increased to $32.5 \mathrm{~g} / \mathrm{h}$ and that of the mangoes also increased to $19.3 \mathrm{~g} / \mathrm{h}$. Olaniyan and Adeoye (2014) reported of a drying rate of $25 \mathrm{~g} / \mathrm{h}$ when charcoal-fired dryer was used for drying a wet produce such as tomato.

Further, the drying rates for each test in terms of the grams of solids present in the sample are given in Table 3. The Table shows the drying rate of pineapple and mango in dry solid matter for different modes of drying. When the dryer was used with backup heater the drying rate of the pineapples was $13.1 \%$ higher than using solar drying alone and $13.8 \%$ higher in the case of mangoes. The implication is that solar drying with back up heater dries about 13-14\% faster than without back up heater.

\section{CONCLUSION}

Solar dryer with a biomass backup heater was designed and constructed using locally available materials. The biomass backup heater, which was adapted from a charcoal stove to serve as a heating component with the purpose of supplying continuous heat for drying after sunset and cloudy periods. The solar collector could attain a maximum air temperature of about $80^{\circ} \mathrm{C}$ when the peak solar radiation was $930 \mathrm{~W} / \mathrm{m}^{2}$. Under no-load condition, the average collector temperature was $56.4^{\circ} \mathrm{C}$; the average drying chamber temperature as $53.3^{\circ} \mathrm{C}$ with ambient temperature of $37.8^{\circ} \mathrm{C}$. In the evening (after sunset) when the biomass backup heater was used, a relatively high average temperature of $50.8^{\circ} \mathrm{C}$ was measured in the drying chamber. This indicated that the temperature in the drying chamber was raised above the ambient temperature creating a suitable condition for drying.

Table 2: Drying rate of the pineapples and mangoes with and without backup heater

\begin{tabular}{lcc}
\hline \multicolumn{1}{c}{ Type of test } & $\begin{array}{c}\text { Drying rate }\left(\mathrm{g} \mathrm{of} \mathrm{H}_{\mathbf{2}} \mathrm{O} \text { removed/g solids/h) }\right. \\
\text { Pineapple }\end{array}$ & Mango \\
\hline Solar drying alone & 23.7 & 15.5 \\
Solar drying with backup heater & 32.5 & 19.3 \\
\hline
\end{tabular}

Table 3: Drying rate of the pineapples and mangoes with and without backup

\begin{tabular}{llc}
\hline Type of Test & Drying rate $\left(\mathbf{g}\right.$ of $\mathbf{H}_{2} \mathbf{O}$ removed/g solids/h) \\
& Pineapple & Mango \\
\hline Solar drying alone & 0.848 & 0.973 \\
Solar drying with backup heater & 0.976 & 1.130 \\
day and night & & \\
\hline
\end{tabular}


The performance of the dryer was evaluated using pineapple and mango in which the moisture content of the sliced pineapples reduced from $87 \%$ to $16 \%$ and sliced mangoes from $85 \%$ to $15.5 \%$. On average, solar drying with backup took 2 days to attain the desired moisture content, while that without took 2-3 days. With biomass backup heater, the drying rate for pineapples was $32.5 \mathrm{~g} / \mathrm{h}$ and $19.3 \mathrm{~g} / \mathrm{h}$ for mangoes, while without backup the drying rate was $23.7 \mathrm{~g} / \mathrm{h}$ for pineapples and $15.5 \mathrm{~g} / \mathrm{h}$ for mangoes. Better dryer performance was obtained when the dryer was used with a biomass backup heater. Given that the dryer could dry both fruits with moisture contents of $85 \%$ and $87 \%$ implies that the solar dryer can dry other crops that have less moisture content than mangoes and pineapples.

\section{ACKNOWLEDGEMENT}

Special thanks go to INTRA-ACP, MIT D-Lab International Development Innovation Network (IDIN) and Technology Consultancy Centre (TCC) of the Kwame Nkrumah University of Science and Technology (KNUST), Kumasi, Ghana, for supporting the construction, experimental set up and acquisition of measuring instruments for data collection. The authors are also grateful to the Department of Agricultural Engineering, KNUST, Kumasi for making their experimental station accessible for the research. These facilities made it possible for us to generate data for this paper.

\section{REFERENCES}

Akoy, E. O. M., Ismail, M. A. and Ahmed, E. A. (2004). Design and construction of a solar dryer for mango slices, University of Khartoum, Khartoum, Sudan.

Alonge, A. F. and Adeboye, O. A. (2012). Drying rates of some fruits and vegetables with passive solar dryers. International Journal of Agricultural and Biological Engineering, 5 (4): 83-90. DOI: $10.3965 /$ j.ijabe. 20120504.0010

Antwi, K. I. (2007). Comparative study of hy- brid solar-gas crop dryer. M.Sc. Thesis. University of Cape Coast, Ghana,. Available online at <http://ir.ucc.edu.gh/dspace/ handle/123456789/441>. [02 October 2014]

Bolaji, B. O. (2005). Development and performance evaluation of a box-type absorber solar air collector for crop drying. Journal of Food Technology, 3(4): 595-600.

Brenndorfer, B., Kennedy, L., Oswin Bateman, C. O., Trim, D. S., Mrema, G. C. and Wereko -Brommy, C. (1987). Solar dryers: their role in post-harvest processing $\left(2^{\text {nd }}\right.$ edn.), The Commonwealth Secretariat, London. ISBN 0 850922828 .

Elepano, A. R. and Satairapan, K. T. (2001). A solar-biomass dryer for pineapple: Proceedings of $51^{\text {st }}$ Philippine Society of Agricultural Engineers National Convection, Cebu, Phillipines, April 23-27

Ertekin, C. and Yaldiz, O. (2004). Drying of eggplant and selection of a suitable thin layer drying model. Journal of Food Engineering, 63(3): 349-359. DOI: 10.1016/ j.jfoodeng.2003.08.007.

FAO, (1997). Fruit processing toolkit: dried fruit. InPho, Food and Agriculture Organization (FAO) of the United Nations, New York.

Forson, F. K., Nazha, M. A. A., Akuffo, F. O. and Rajakaruna, H. (2007). Design of mixedmode natural convection solar crop dryers: application of principles and rules of thumb. Journal of Renewable Energy, 32 (14) : 2306 -2319 .

Fudholi, A., Othman, M. Y., Ruslan, M. H., Yahya, M., Zaharim, A. and Sopian, K. (2011). Design and testing of solar dryer for drying kinetics of seaweed in Malaysia. In: Mastorakis et. al.(Editor), Recent Researches in Geography, Geology, Energy, Environment and Biomedicine, World Scien- 
tific and Engineering Academy and Society (WSEAS), Corfu Island, Greece, July 14-16. Pg: 119-124. ISBN: 978-1-61804-022-0.

Green, M. G., and Schwarz, D. (2001). Solar drying technology for food preservation. Gate Information Service/GTZ, Eschborn, Germany. Available online at <http:// www.armageddononline.org/uploads/Food__Solar_Food_Drying.pdf>. [22 June 2014]

Hii, C. L., Jangam, S. V., Ong, S. P. and Mujumdar, A. S. (2012). Solar drying: fundamentals, applications and innovations. Transport Phenomena Group, Singapore, ISBN 978-981-07-3336-0. p 150.

Mercer, D. G. (2007). An intermediate course in food dehydration and drying. Department of Food Science, University of Guelph, Ontario, Canada. Available online at $<$ elearning.iufost.org/sites/default/files/ Intermediate-Outline-1.pdf $>$. [30 September 2014]

Moujaled, J. K. (2014). A comparative assessment of solar resource database, simulations and ground observations for Kumasi. M.Sc Thesis. Kwame Nkrumah University of Science and Technology, Kumasi, Ghana. Available online at <http://ir.knust.edu.gh/ bitstream/123456789/6508/1/Jale1\% 20kobina\%20Moujaled.pdf>. [10 December 2014]

Olaniyan, A. D. and Adeoye, O. A. (2014). Conceptual design of a charcoal-fired dryer: Proceedings of International Conference of Agricultural Engineering, Zurich, July 6-10.

Raju, R. V. S., Reddy, R. M. and Reddy, E. S. (2013). Design and fabrication of efficient solar dryer. Journal of Engineering Research and Applications, 3(6): 1445-1458.

Sanni, L. O., Onadipe-Phorbee, O. and Alenkhe, E. B. (2012). Low-cost sustainable cassava drying technologies in West Africa:
Solar dryer with biomass backup heater... 24

A compendium of information, design, fabrication and pilot testing. IITA/CFC-WA Project Report, Nigeria.

Scanlin, D. (1997). The design, construction and use of an indirect, through-pass, solar food dryer. Homebrew, 57:. Appalachian. Accessed online on 02 August 2014 from $<$ http://www.homepower.com/view/? file=HP57_pg62_Scanlin>.

Seveda, M. S. (2013). Design of a photovoltaic powered forced convection solar dryer in $\mathrm{NEH}$ region of India, International Journal of Renewable Energy Research, 3(4): 1-7.

SolarFlex, (2013). Drying fruits and vegetables with the SolarFlex dryer. Technical Specifications of SolarFlex Small Farm Dryer. Available online at <htp:// www.postharvest.org/Drying\%20Fruits\% 20 and $\% 20$ Vegetables $\% 20$ with $\% 20$ the $\%$ 20SolarFlex\%20Dryer.pdf $>$. [15 December 2014]

Svenneling, J. (2012). Constructing a solar dryer for drying of pineapples: implementing a solar dryer for sustainable development in Ghana. Karlstands University, Netherlands.

United Nations (2013a).UNECE standard DDP -28 concerning the marketing and commercial quality control of dried pineapples, Geneva, (pp. 7). Available online at $<\mathrm{http}: / /$ www.unece.org/fileadmin/DAM/trade/agr/ $\mathrm{s} \mathrm{t}$ a n d a r d / d r y / S t a n d a r d s / DDP28_DriedPineapples_2014_e.pdf>. [10 March 2015]

United Nations (2013b). UNECE standard DDP -25 concerning the marketing and commercial quality control of dried mangoes, Geneva, (pp. 6). Available online at <http:// www.unece.org/fileadmin/DAM/trade/agr/ $\mathrm{s} \mathrm{t}$ a $\mathrm{n} \mathrm{d}$ a r d / d r y / d r y DDP25_DriedMangoes_2013_e.pdf $>$. [10 March 2015] 


\section{Tibebu et al.}

Weiss, W. and Buchinger, J. (2002). Solar drying. Austrian Development Cooperation,

intec.at/0uploads/dateien553.pdf>. [17 June Austria. Available online at $<\mathrm{http} / / /$ t.aee-

2014] 